\title{
HUMAN RIGHTS IN THE HORN OF AFRICA
}

\author{
Anonymous
}

\section{THE CONCEPT OF HUMAN RIGHTS}

The framework of constitutional law and international law encompasses the notion of human rights, and human rights advocates strive to defend "human beings against abuses of power committed by the organs of state and at the same time to promote the establishment of human living conditions." The international community applies numerous principles and rules of interstate cooperation to provide favorable conditions both in peacetime and in wartime.

The following general principles describe human rights as an institute of international humanitarian law (the modem branch of international law):
a) "human rights constitute a judicial notion;"2
b) two branches of law pertain to international human rights, municipal and international; ${ }^{3}$
c) "human rights pertain to the citizen and to man;"
d) the notion of human rights protects the fundamental rights and freedoms of citizens and men both in peace and during periods of armed conflict;
e) human rights contain a number of basic principles of which the most important are:
(i) the principle of promotion of and respect for fundamental human rights and freedoms;
(ii) the principle of equality and non-discrimination in all forms and manifestations;
f) the concept of human rights has a universal character;
g) human rights stem from the concept of the inalienable rights of man, which derive from natural law.

1. Imre Szabo, Historical Foundations of Human Rights and Subsequent Developments, in 1 THE INTERNATIONAL DIMENSIONS OF HUMAN RIGHTS 11 (Karel Vasik ed., 1982).
2. Id.
3. See id.
4. Id 


\section{HISTORICAL BACKGROUND OF HUMAN RIGHTS}

The concept of human rights dates back to ancient Greece, ${ }^{5}$ when the ancient Greek philosophers first considered this issue. ${ }^{6}$ In approximately 400 B.C., Sophist Antiphon argued that all people, Ellines and Barbars, the powerful and the ordinary, are equal in nature and thus have a common natural interest. Discrimination among peoples evolved from man-made laws not from nature. In nature, all people are equal in all relations. ${ }^{7}$

Roman law envisioned the concept of natural law from which flowed man's natural rights. One Roman philosopher asserted that "natural law is that which nature teaches to all living beings." Natural law also correlates to jus gentium, which has two prongs. First, it describes the rights of non-Romans and "refers to those rights to which men are entitled wherever they go." Second, it includes rights that emanate from international law.

One major facet of human rights is the right to equality "with regard to ownership and the acquisition and enjoyment of property." Scholars and philosophers disagree about whether the right to own property is a natural right that is fundamental and inalienable. For example, Thomas Aquinas believed that the right to property was a fundamental and inalienable right that flowed from natural law. " Grotius, on the other hand, argued that the right to property did not derive from natural law but instead was introduced by manmade law. ${ }^{12}$ However, Grotius concluded that the right to property correlates with the conception of natural law even if that right falls outside the sphere of natural law. ${ }^{13}$

Human rights law also originates from positive law documents. ${ }^{14}$ These documents include charters, bills, petitions, and various declarations. ${ }^{15}$ One of the earliest examples is the Magna Carta, also known as the Great Charter of Runnymede (Great Charter), which was acceded to by King John in 1215. The Great Charter guaranteed the freedoms of the church, restricted taxes and fines, and promised justice to all. ${ }^{16}$ The Magna Carta declared in article 39: "No freeman shall be seized, or imprisoned, or dispossessed, or outlawed, or in any way destroyed; nor will we condemn him, nor will we commit him to

5. See id.

6. See 1 The International. Dimension of Human Rights II (General Wood Press, UNESCO 1982).

7. See History OF POLTICAL AND Legal STUdies 56 (2d ed. 1988).

8. Szabo, supra note 1 , at 12.

9. Id.

10. Id.

11. See id. at 13.

12. See id.

13. See id. at 14.

14. See id.

15. See id.

16. See OXFORD DICTIONARY OF LAW 177 (4th ed. 1997). 
prison, excepting by the legal judgment of his peers, or by the laws of the land."17 Another example is the Habeas Corpus Act of 1679, which delineated a basic component of human rights law. Habeas Corpus is "a writ employed to bring a person before a court, most frequently to ensure that the party's imprisonment is not illegal."18 Persons wrongfully imprisoned may thereby challenge the legality of imprisonment without trial. The Habeas Corpus Act declared that if, upon an application for the writ, the court or the judge is satisfied that the detention is prima facie unlawful, the custodian must appear and justify it, failing to do so would mean that release should be ordered. ${ }^{19}$ Finally, the Bill of Rights of 1689 also exemplifies a positive law document that provides a source of human rights; this document limited the power of the monarchy and declared some basic rights and freedoms for English citizens. ${ }^{20}$

The French Revolution and the Declaration of the Rights of Man and of the Citizen provide a starting point for the development of human rights in the modern sense of the term. The French Declaration of the Rights of Man and of the Citizen of 1789 and other similar documents distinguish between the rights of man as an individual and the rights of citizen as a member of society. ${ }^{21}$ The rights of the man derive from natural law whereas the rights of the citizen derive from the positive law established by the state. ${ }^{22}$ Because man may exist outside of society and because man's inherent rights derive from natural law, these rights are inalienable. The rights of the citizen, however, are positive rights granted by the positive law that the state as an organ of society develops. ${ }^{23}$ The natural law rights that pertain to man are therefore superior to the rights given by the state to citizens because they are inalienable and cannot be taken away. The rights of the citizen derive from the state and are therefore dependent upon the state.

Another important document that contributed to the development of human rights law is the U.S. Constitution. The U.S. Constitution prescribes not only the basic elements of human rights expressed in the aforementioned positive law documents but also elaborates upon and advances these basic elements of human rights. ${ }^{24}$ The United States prescribed the basic rights and freedoms of it citizens with the U.S. Constitution. Founding father Alexander Hamilton suggested that the Constitution is itself a Bill of Rights. ${ }^{25}$ The first ten amendments to the U.S. Constitution are the Bill of Rights, and they protect individuals from the state. ${ }^{26}$

17. Magna Carta, 1215, available at http://magna-carta.net/.

18. BLACK'S LAW DiCTIONARY 284 (1998).

19. See Intemational Acts on Human Rights, in COLLECTED DOCUMENTS 4 (1998).

20. See id. at 14-18.

21. See Szabo, supra note 1, at 15.

22. See id.

23. See id.

24. See U.S. CONST.

25. See THE FEDERALIST No. 84 (Alexander Hamilton).

26. U.S. CONST. amends. I-X. 
Human rights first emerged as an international concern in the aftermath of the atrocities committed against humanity by the Nazis during World War II. These cruel acts finally led to the "official" adoption of measures designed to ensure the international protection of human rights. Before and during World War II numerous proposals and privately sponsored measures were introduced which resulted in the Universal Declaration of Human Rights (UDHR). The U.N. Commission considered a total of eighteen drafts prior to adopting the UDHR in 1947. President Roosevelt's January 26, 1941, declaration on the Four Freedoms - freedom of opinion and expression, freedom of worship, the right to be free of material want, and the guarantee of life without fear - provided the impetus for the Atlantic Charter, drawn up on August 11, 1941, by Roosevelt and Churchill. The Atlantic Charter expanded upon the Four Freedoms and included the need for economic progress and social security. The Atlantic Charter was a precursor to the U.N. Declaration which incorporated the terms of the Atlantic Charter and elevated its stipulations to the level of international duties. ${ }^{27}$ Thereafter, the UDHR has become the fundamental guideline for the adoption of regional documents on human rights. The UDHR, proclaimed by the General Assembly on December 10,1948 , recognizes the fundamental rights and freedoms of human beings in its preamble. ${ }^{28}$ The preamble to the UDHR states that "the recognition of the inherent dignity and of the equal inalienable right of all members of the human family is the foundation of freedom, justice and peace in the world."29

The UDHR provided the guideline for the European Convention on the Protection of Human Rights and Fundamental Freedoms (European Convention), which was adopted in Rome on November 4, 1950, and entered in to force on September 3, 1953. ${ }^{30}$ The European Convention in its preamble directly alludes to the provisions and principles of the UDHR. ${ }^{31}$ Similarly, the American Declaration of the Rights and Duties of $\mathrm{Man}^{32}$ (adopted in Bogotá on May 2, 1948) in its preamble conveys the same idea that is expressed in article 1 of the UDHR. The American Declaration phrases the call for peace and international harmony as follows, "All men are born free and equal, in dignity and in rights, and, being endowed by nature with reason and conscience, they should conduct themselves as brothers one to another." 33

27. See Szabo, supra note 1, at 20-22.

28. G.A. Res. 217, A(III), U.N. Doc. A/810, at 71 (1948).

29. Id.

30. [European] Convention for the Protection of Human Rights and Fundamental Freedoms, entered into force Sept. 3, 1953, as amended by Protocols Nos. 3, 5, and 8 which entered into force on 21 Sept. 1970, 20 Dec. 1971, and 1 Jan. 1990, respectively.

31. See id.

32. American Declaration of the Rights and Duties of Man, O.A.S. res. XXX, adopted by the Ninth International Conference of American States, Bogota (1948): Novena Conferencia Internacional Americana, 6 Actas y Documentos 297-302 (1953).

33. Id. 
The African Charter on Human and People's Rights (African Charter), adopted in Nairobi on June 26, 1981, also follows the lead of the UDHR. ${ }^{34}$ The African Charter pledges to "eradicate all forms of colonialism from Africa, to coordinate and intensify their cooperation and efforts to achieve a better life for the peoples of Africa and to promote international cooperation having due regard to the Charter of the United Nations and the Universal Declaration of Human Rights." ${ }^{35}$ Other international instruments that follow the guidelines of the UDHR include the International Covenant on Civil and Political Rights (ICCPR), ${ }^{36}$ adopted in 1966 and entered into force on March 23, 1976; the International Covenant on Economic, Social and Cultural Rights (ICESCR), ${ }^{37}$ adopted in 1966 and entered into force on January 3, 1966; the Optional Protocol to the International Covenant on Civil and Political Rights, ${ }^{38}$ adopted in 1966 and entered into force on March 23, 1976; and the Second Optional Protocol to the International Covenant on Civil and Political Rights, ${ }^{39}$ aimed at the abolition of the death penalty and adopted in 1989. All of the aforementioned covenants and optional protocols are based on the UDHR.

The importance of the Optional Protocol to the ICCPR is that it recognizes the competence of the committee to receive and consider communications from individuals subject to its jurisdiction who claim to be victims of a violation by a state party of any of the rights set forth on the covenant. $^{40}$ However, in accordance with article 5 of the Optional Protocol, "[t]he Committee shall not consider any communication from an individual unless it has ascertained that: a) [t]he same matter is not examined under another procedure of international investigation; b) [t]he individual has exhausted all available domestic remedies." 41 Thus, the Optional Protocol provides an appeal to the U.N. for assistance with individual human rights violations only after all avenues of domestic relief have been pursued.

Because it is not easy for an ordinary person whose rights and freedoms are violated by state authorities to be able to submit all arguments necessary

34. African [Banjul] Charter on Human and Peoples' Rights, adopted June 27, 1981, OAU Doc. CAB/LEG/61/3 rev. 5, 21 I.L.M. 58 (1982), entered into force Oct. 21, 1986.

35. Id.

36. G.A. Res. 2200 A (XXI), 21 U.N. GAOR, Supp. No. 16, at 52, U.N. Doc. A/6316 (1966), 999 U.N.T.S. 171, entered into force Mar. 23, 1976.

37. G.A. Res. 2200A(XXI), 21 U.N. GAOR, Supp. No. 16, at 49, U.N. Doc. A/6316 (1966), 993 U.N.T.S. 3, entered into force Jan. 3, 1976.

38. G.A. Res. 2200A (XXI), 21 U.N. GAOR Supp. No. 16, at 59, U.N. Doc. A/6316, 999 U.N.T.S. 302, entered into force March 23, 1976 [hereinafter Optional Protocol].

39. G.A. Res. 44/128, 44 U.N. GAOR Supp. No. 49, at 207, U.N. Doc. A/44/49, entered into force July $11,1991$.

40. See Optional Protocol, supra note 38, art. 1 (explaining that a party to this agreement "recognizes the competence of the Committee to receive and consider communications from individuals subject to its jurisdiction who claim to be victims of a violation by that State Party of any of the rights set forth in the Covenant").

41. Id. art. $5, \S 2(a),(b)$. 
to convince a U.N. committee that he has exhausted all available domestic remedies, the fates of many victims have remained the prerogative of the state authorities. Although there are many other international and regional conventions that pertain to the protection of human rights, the aforementioned instruments (the UDHR and its progeny) are the basic and fundamental instruments for the further development of human rights at the universal and regional level. Other universal and regional conventions or declarations recently adopted are derived from the basic principles espoused in the UDHR.

\section{HUMAN RIGHTS DEVELOPMENTS IN ETHIOPIA, ERITREA, SUDAN, AND SOMALIA}

Human rights have constantly been violated in African countries, especially so in East African countries irrespective of the existing international and regional instruments dedicated to human rights. Almost no good news is heard concerning human rights in East African countries.

\section{A. Human rights in Ethiopia}

In comparison with the prior Ethiopian government the Transitional Government of Ethiopia (TGE) has effectuated significant improvement of the human rights situation in the country since the overthrow of the government of Colonel Mengistu Haile Mariam in May, 1991. The overthrow of the Mariam regime ended seventeen years of rule of the Dergue. In its early days, the TGE adopted a transitional charter (the Charter) which guaranteed basic human rights, and the Government ratified major international human rights instruments and permitted the emergence of more political parties and other associations than ever before in the history of Ethiopia. When the government issued the Basic Freedom of the Press Proclamation, ${ }^{42}$ about two hundred licences were issued for independent journals and newspapers. In addition, the TGE took initial steps to support rehabilitation of former refugees returning from neighbouring countries.

The Government also acted effectively through its Relief and Rehabilitation Commission to avert the imminent famine, which threatened a great number of people in 1994. The systematic "disappearances" and massive extra-judicial executions that characterised the Dergue regime were no longer part of the general human rights situation in Ethiopia.

The TGE also adopted the Peaceful Demonstration and Public Political Meeting Proclamation, ${ }^{43}$ which guarantees the right to peaceful demonstration and public political meetings. ${ }^{44}$ However - unlike the economy which was

42. See Proclamation N34/1992.

43. Proclamation N3/1991.

44. See HuMAN RIGHTS WATCH, WORLD REPORTS OF 199516 (New York, Washington, Los Angeles, Brussels). 
doing relatively well and where for the last seven years the average development of gross national product reached more than $7 \%$ and $10 \%$ in $1996^{45}$ - the political situation in Ethiopia appeared to be deteriorating, and tension was mounting. Hundreds of thousands of former soldiers were left without means of support. Proclamation N3/1991 was largely ignored or misinterpreted depending on the region in which an application was made.

Although the law did not require political parties to obtain permission to hold public meetings, permits were, nevertheless, generally required. Furthermore, permission was often denied or delayed to the extent that parties such as the Ethiopian Democratic Union Party (EDUP), the All Amahara People's Organisation (AAPO), and the Council of Altemative Force for Peace and Democracy in Ethiopia (CAFPDE), did not have the time to organize effectively or to inform the public of their activities.

The harassment of political opponents extended to personal intimidation and harassment of party members and officials. Members of the Sidama Liberation Movement (SLM) and the Ogadeni National Liberation Front (ONLF) were not only arrested and detained with out charge or trial but were also killed. A number of AAPO members were held at Alem Bekagne (World's End), the central prison in Addis-Ababa, on different charges and without bail. Many members and supporters of Oromo Liberation Front (OLF), the main organization that helped the Ethiopian People's Revolutionary Democratic Front (EPRDF) form the transitional Government in 1991, were still detained in Hurso, Eastern Ethiopia. ${ }^{46}$ Unequal access to the mass media was another major concern in the democratisation process. Pursuant to a council of representative's decision, all of the twenty-five or more political parties that were legally registered in May 1994 were to be given regular access to television and radio air time. However, this decision was not honoured.

On June 5, 1994, when elections were held for the constituent Assembly, the body responsible for debating and enacting the draft constitution, the major opposition political parties boycotted the elections for the Assembly on the grounds that they had been excluded from participation in the drafting of the constitution. Consequently, candidates representing the EPRDF won 464 of the 548 seats $(84.7 \%)$. It became increasingly difficult to distinguish between the EPRDF as a political party and the EPRDF as the government in power. ${ }^{47}$ The government's ongoing suppression of freedom of the press heightened the feeling of anxiety, fear, and confusion in the country. In the first six months of 1994, a number of journalists were either detained or subjected to fines for their writings that criticized the government. The press law (Press

45. See Federal Democratic Republic of Ethiopia, in ETHIOPIA TODAY, ETHOPIAN EMBASSY TO RUSSIAN FEDERATION 3 (1998).

46. See HUMAN RIGHTS WATCH, WORLD REPORT, supra note 44, at 17.

47. See id. at 18. 
Proclamation N/1992) ${ }^{48}$ contains such vague and ambiguous language regulating the content of what journalists may write that it can easily be abused and manipulated by the government to harass journalists by bringing criminal charges against journalists who are critical of government policies or action and by setting bail too high for them to be discharged awaiting trial. ${ }^{49}$

The 1997 Report of the U.N. Special Rapporteur on Torture documents the ongoing human rights violations and consistent allegations of torture, particularly as perpetrated against persons suspected of involvement with the OLF. $^{50}$ Extra-judicial, summary, or arbitrary executions, as well as other human rights violations occurred in secret detention centres, ${ }^{51}$ although the Ethiopian government reportedly denies the existence of such centres. Ethiopia is still not a party to the Convention Against Torture and Other Cruel, Inhuman or Degrading Treatment or Punishment (CAT) which was adopted by the General Assembly in 1984 and entered into force on June 26, $1987 . .^{52}$ Furthermore, Ethiopia is still not a party to the Optional Protocol to the ICCPR, ${ }^{53}$ which permits individuals who claim to be victims of violations of the rights set forth in the ICCPR to submit communications containing allegations of these violations to the U.N..

Much concern centers on the violations and abuses of human rights in Ethiopia by a minority that currently holds all political power under the pretext of the current Ethiopian constitution, which grants almost all political power to the Prime Minister who belongs to the leading opposition political party in Ethiopia. Many observers blame the centralized means of government (adopted by both the Imperial and Dergue Regimes) for the persistent human rights abuses. However, the TGE government began implementing a policy of decentralizing authority to regional administrations. The TGE implemented this policy by dividing Ethiopia into nine Subjects of Federation (collectively known as the Federation) and distributing authority accordingly. The foremost challenge in Ethiopia with regard to this redistribution of authority is finding a way to bring about participatory development to ensure not only that the fruits of development are equitably distributed in the country, but that people, especially those at the regional, woreda (district), and grass roots levels are given a chance to participate in the determination of their own destiny.

After the formation of the Federation, many local and/or ethnic groups expressed dissatisfaction. However, on May 6, 1998, war broke out between Ethiopia and Eritrea, and the Ethiopian people shifted their attention from

48. Proclamation N34/1992.

49. See id. art. 2.4(C).

50. See U.N. ESCOR, 54th Sess., Item 8(a), at 16, U.N. Doc. E/CN.4/1998/38 (1997), available at http://www.hri.ca/fortherecord 1998/documentation/commission/e-cn4-199838.htm.

51. See id.

52. G.A. Res. 39/46, annex, 39 U.N. GAOR Supp. (No. 51), at 197, U.N. Doc. A/39/51 (1984), entered into force June 26, 1987.

53. Optional Protocol, supra note 38. 
dissatisfaction with the political practices of the government toward the war. The Ethiopian people fought the Eritreans for the protection of their territorial integrity.

The active participation of all Ethiopian people and the contribution of materials and moral support enabled the end of the war after nineteen intense fighting days (from May 12 through May 31, 2000). Since then, some progressive developments have taken place. For example, on June 18, 2000, the Agreement on Cessation of Hostilities between Ethiopia and Eritrea was signed under the oversight of the Current Chairman of the Organization of African Unity (OAU), Abdelaziz Boutefilka. ${ }^{54}$ At the request of both parties, the Security Council created the United Nations Mission in Ethiopia and Eritrea (UN MEE) (o $^{55}$ to further the OAU brokered peace process, and the two countries signed a peace agreement in Algiers on December 12, 2000. ${ }^{56}$ Since then, the efforts of the Red Cross and the commitment of both governments have made possible the exchange of prisoners of war, and many former prisoners have been reunited with their families and loved ones.

However, a serious problem awaited those prisoners who returned back home - people displaced as a result of war. "[T]he government of Ethiopia and the U.N. Country Team estimated that 349,837 people had been displaced as a result of the conflict in the northern regions of Tigray and Afar" in January, 2000..$^{57}$ Moreover, the drought exacerbated the complex emergency situation in Ethiopia, and over ten million people, including over 1.4 million children under the age of five, need emergency food assistance. ${ }^{58}$

In light of the aforementioned problems (the infringement of basic human rights such as freedom of expression, the right to be free from torture, and the right to be free from hunger), the current Ethiopian government must maintain the federalist principle that separates and divides power in order to provide checks and balances on the exercise of authority. Furthermore, the government should strive to minimize human rights violations. If something is not done to address human rights violations in Ethiopia, the current conditions could cause mass strikes and demonstrations which might result in economically, socially, and politically catastrophic consequences. Active Ethiopian political participants should enhance the human rights situation in Ethiopia and try to revise their policies for the well-being of the Ethiopian people.

54. See Report of the Secretary-General on Ethiopia and Eritrea, U.N. SCOR, at 10, U.N. Doc. $S / 2000 / 643$ (2000).

55. See U.N. SCOR, 55th Sess., 4181 st mtg., at 10, U.N. Doc. S/RES/1312 (2000).

56. See Jos van Buerden, End in Sight to a Devastating War?, at http://www.oneworld.org/euconflict/sfp/part2/132_htm (last visited May 26, 2001).

57. Report of the Secretary-General on Ethiopia and Eritrea, U.N. SCOR, 55th Sess., S/2000/879.

58. See id. 


\section{B. Human Rights in Eritrea}

As with Ethiopia, violations continue to occur in the recently emerged state of Eritrea. The human rights of the people of Eritrea continue to be violated even worse than in Ethiopia. The people of Northern Ethiopia and those in highland Eritrea are one in the same people, separated only by historical accident. From 1890 to 1941 , Eritrea was an Italian colony. In 1941, it became a British territory and was governed by Britain until 1952, when Eritrea was federated with Ethiopia. Emperor Haile Selassie abrogated the Federation in 1962. Some scholars believe that the abrogation of the Federation sparked the 30-years War of Independence. De facto independence was achieved in May, 1991, and was formalized in 1993 following a referendum concluded in Eritrea. ${ }^{59}$

The Eritrean People's Liberation Front (EPLE), also known as the Sha'ebia, evolved from the ranks of the Eritrean Liberation Front (ELF), also known as the Jebha. Although the EPLE was formed as a democratic alternative to the ELF, it never developed a democratic culture. The EPLE was bent on destroying the ELF right from the start, and it was never willing to entertain the existence of other movements in Eritrea. When the referendum was announced, there was a great deal of euphoria and merry-making. But in reality, Eritrea is ruled by a relentless dictator who rules with an iron fist. There is no respect for basic human rights, no freedom of speech, and no freedom of expression and association. The treatment of disabled Eritrean veterans provides a good example. These disabled veterans took to the streets to protest the inhuman conditions in which they were living, and they were mowed down with gunfire without mercy and many were left dead. Many diverse nations and nationalities comprise the population of Eritrea, but freedom is curtailed. There are no political parties, and there is not an elected government. ${ }^{60}$ Since it gained its independence, Eritrea has not joined the basic international conventions dedicated to human rights. Eritrea is a party to only two conventions - the Convention on the Rights of the Child ${ }^{61}$ and the Convention on the Elimination of All Forms of Discrimination Against Women. ${ }^{62}$ Eritrea recently emerged in the world as a newly sovereign state. However, instead of building its statehood internally by securing social guarantees that protect human rights and externally by establishing good political and economic relations with neighbouring countries, Eritrea authorizes itself as a hero of wars against neighbouring countries. The war between Ethiopia and Eritrea resulted in a catastrophic end for Eritrea, and the

59. See 4:2 ETHOPLAN SCOPE 7 (1998).

60. See id. at 10-11.

61. G.A. Res. 44/25, annex, 44 U.N. GAOR Supp. (No. 49), at 167, U.N. Doc. A/44/49 (1989), entered into force Sept. 2, 1990.

62. G.A. Res. 34/180, U.N. GAOR Supp. (No. 46), at 193, U.N. Doc. A/34/180, entered into force Sept. 3, 1981. 
country should focus on its existence as one of the sovereign states of the world rather than the heroism of a bygone war.

\section{Human Rights in Somalia}

Following the collapse of the central government and consequently law and order, wide spread famine crept over Somalia in 1992. The U.N. Commission on Human Rights spotlighted human rights concerns in Somalia. "The resolution created a mandate for an independent expert to report on the human rights situation in Somalia and to study ways and means of best to implements a programme of technical assistance." ${ }^{163}$

Refugees and internally displaced persons are a matter of concern in Somalia as in other East African countries. In November and December, 1997. torrential rains caused flooding in some areas in the South, which was already burdened with an influx of international displaced persons. United Nations agencies noted in December, 1997, that the total number of displaced persons was at least 230,000 and the number of people who remained at risk was approximately $1,000,000 .^{64}$ By January 5,1997 , the death toll reportedly reached 1904..$^{65}$ Most Somalis are either refugees in countries such as Djibouti, Ethiopia, Kenya, or Yemen or displaced within Somalia due to the mass displacement caused by flooding and famine. ${ }^{66}$. International relief agencies asserted that they would enhance relief efforts aimed at assisting internally displaced persons if the donor community would generate greater interest in such programs. ${ }^{67}$

Somalia lacks a centralized government, as it has for several years. In 1997, disturbing attacks against international humanitarian works hampered relief efforts in some parts of Somalia. One particularly disturbing incident, which occurred in Baidoa, involved the assassination of thirty-five year old Dr. Ricardo Marques of Portugal on June 20, 1997. Dr. Marques worked for the international humanitarian agency, Médecins Sans Frontiéres (MSF). Another foreign doctor who accompanied Dr. Marques escaped without harm, and the authorities could not determine the reason for the murder. As a result of this tragic incident, MSF suspended its activities in Bardera, Baidoa, and Tiaglo. The Somalia Aid Coordinating Body (SACB) (made up of donors, U.N. agencies, international nongovernmental organizations (NGOs), and other international organizations) reacted by demanding the government bring the murderers to justice and "recommended the withdrawal of all the aid agencies

63. Question of the Violation of Human Rights and Fundamental Freedoms in Any Part of the World, With Particular Reference to Colonial and Other Dependent Countries and Territories, U.N. ESCOR, 54th Sess., Item 10, U.N. Doc. E/CN4/1998/96 (1998).

64. ld.

65. ld.

66. See id.

67. See id. 
from the region with immediate effect and the suspension of all activities." 68 Based upon this recommendation, all humanitarian agencies withdrew from Somalia. ${ }^{69}$ The absence of an organized and centralized government in Somalia and the constant flow of refugees to the neighboring countries gradually caused the country to lose some of its identity as a state, and the absence of a communication infrastructure contributed to a lack of information about Somalia being dispersed to the international community.

To some extent, the status of women in Somalia has become parallel to the status of men. Because most Somali men were involved in the fighting, many were killed, became refugees, or became internally displaced persons. This led to dissolution of family unity and caused the loss of the traditional male as an economic provider. Somali women stepped in to support their families, and many became heads of households.

The U.N. independent expert, Special Rapporteur Mona Rishmawi, studied the justice system in Somalia and concluded that there were "no uniform rules governing, private, social or economic behaviour in Somalia ...."70 Somali communities do not apply consistent rules; the rules of the various communities are based upon either the traditional Shari'a law or upon Somali law as applied by former President Said Barre's regime, the prior regimes (before the Barre takeover in 1969), or a combination of these laws. ${ }^{71}$ Furthermore, Special Rapporteur Rishmawi noted that uniformed forces carry out most regular police functions in Hargeisa, the unrecognised breakaway state of "Somaliland." The regular police force, though quite weak, still exists, and it continues efforts to ensure peace while performing daily law enforcement activities. ${ }^{72}$

Despite the difficult conditions, Somali human rights groups continued their efforts to alleviate the suffering and assist the U.N. Special Rapporteur. The two main Somali human rights groups are located in "Somaliland" and northern Mogadishu. In Somaliland, the Horn of Africa Human Rights Watch Committee and the Guardians for Civil Liberties assisted the U.N. Special Rapporteur. In addition, these groups monitor the human rights situation, provide aid to victims of human rights violations, and intervene with the authorities. In Mogadishu, human rights are advocated by the Dr. Ismail Juma'le Human Rights Organization. ${ }^{73}$ According to the independent expert, these groups receive little funding and have limited resources while operating under arduous conditions. The recently established transitional government of Somalia faces a tremendous task in addressing the current human rights abuses in that country.

68. Id.

69. See id.

70. Id.

71. See id.

72. See id.

73. See id. 
In order to normalize the situation and rebuild the nation, the transitional government of Somalia must facilitate the security of the country and permit international agencies, humanitarian organizations, and donor governments to deliver humanitarian assistance to all war-affected civilians. In addition, the government must put forth an effort to proactively attract donors and volunteers who will assist the nation and its people and provide support.

\section{Human Rights in Sudan}

The human rights situation in Sudan continues to worsen. Sudan is governed by a militaristic group called National Islamic Front (NIF) whose policies have dismantled civil society. It is through force that laws and policies which discriminate against non-Muslim men and women are enforced. Even civil and political rights for Muslim men are not recognized because they were suspended by a Draconian set of emergency rules established when the Juba seized power in 1989. While under the rule of the NIF, the human rights situation in Sudan has continued to worsen. The current laws ban political parties and independent trade unions, and there is no prospect for freedom of association or expression under the present regime. In addition, torture and arbitrary detention pervade the human rights picture in Sudan, and many Sudanese; specifically those who are black Christians living in southern Sudan, are enslaved and abused. ${ }^{74}$

As the largest country in Africa, Sudan is ethnically and religiously diverse. However, the current government seems determined to impose one mold of Arabism and militant Islam on the population. The government's policy is to impose its version of Islamic Shari'a law on both Muslim and nonMuslim segments of the population. The government's strategy is a "calculated plan ... to make the community expression of the Christian faith extremely difficult, particularly by preventing Christians from having places of worship and by destroying the places they have built." 75

The government also developed an urban clearance program to remove the large non-Muslim population of war-displaced southern and Nubian peoples from the greater Khartoum area to isolated sites, back to their home areas, or in displaced persons camps. ${ }^{76}$ With little or no notice, the displaced, who initially fled for safety and work in the north, were forced home to the south only to find their homes destroyed without compensation as the result

74. See Question of the Violation of Human Rights and Fundamental Freedoms in Any Part of the World, With Particular Reference to Colonial and Other Dependent Countries and Territories, Situation of Human Rights in the Sudan, U.N. ESCOR, 54th Sess., E/CN.4/1998/66 (1998) [hereinafter Situation of Human Rights in the Sudan].

75. Id.

76. See HUMAN RIGHTS WATCH, HUMAN RIGHTS WaTCH WORLD REPORT 1998 SUDAN 3 (1998), at http://www.hrw.org/hrw/worldreport/Africa-12.htm (last visited May 28, 2001). 
of this clearance program. ${ }^{n}$ The clearance program also forces the displaced southern Sudanese, mainly black Nubian Christians, to live in areas that lack a sufficient water supply and are devoid of employment opportunities. ${ }^{78}$ The security forces killed the squatters who protested the government's attempts to destroy their settlements and remove them to primitive sites in the desert far outside Khartoum.

The primary goal of the government is to promote its policies of "Arabization" and "Islamization." 79 Under the pretext of the program, the NIF government flouts child welfare laws and procedures and gives boys Muslim names and religious instruction in Islam regardless of the fact that most boys affected by the laws do not come from Muslim families. The northern political opposition that formerly found expression in political parties remains severely repressed; parties, leaders, and activists who do not belong to the NIF are banned. ${ }^{80}$ Many people who have remained in the country, including those who associated with political parties other than the NIF, doctors, lawyers, professors, students, and engineers, are periodically arrested. ${ }^{81}$ These arrests often occur without charges, and those who are arrested are frequently mistreated or tortured. ${ }^{82}$ The government banned all of the independent press after the 1989 coup.

The government has denied human rights organizations the right to monitor since 1989; both the Sudan Human Rights Organization (SHRO) and the Bar Association were effective Sudanese human rights monitors prior to the 1989 coup. The SHRO since then has been banned, and the Bar Association was taken over by government supporters in 1993 . Therefore, the Sudan Bar Association advocates the official government policies and no longer serves as an independent human rights voice. ${ }^{83}$

International communities have tried to stabilize the human rights situation and have criticized the government of Sudan for its frequent violations of human rights. The United States, the U.N., and the European Union (EU) condemned the frequent violations of human rights and expressed

77. See id.

78. See id.

79. Interview by Geoff Metcalf with Dr. Peter Hammond, Director of Frontline Fellowship (May 27, 2001), available at http://www.worldnetdaily.com/news/ article.asp?22976.

80. See HUMAN RIGHTS WATCH WORLD REPORT 1998, supra note 76, at 1. However, some members of the NIF recently advocated a return to a multi-party system. See id.

81. See Situation of Human Rights in the Sudan, supra note 74.

82. Id. The report detailed torture at the hands of security forces that included: beatings, electric shocks, exposure to the sun for hours which, in the given conditions, can result in disfigurement and other lasting skin diseases, pouring of cold water on the naked body, rape in custody and threatening with rape, deprivation of sleep, refusal of food and medical treatment and forcing some detainees to witness the torture of others. See id.

83. See HUMAN RIGHTS WATCH, WORLD REPORTS 199555 (1995). 
concern over the indiscriminate bombing of civilians and the use of violence by the government to repress the demonstrators. Human Rights Watch/Africa has maintained pressure on the government of Sudan by publishing and widely disseminating a series of reports on human rights abuses in the war zones and in the north and by advocating a program of U.N. human rights monitors to promptly investigate and intervene with the government and the rebels on human rights issues. ${ }^{84}$

Despite the international community's efforts to enhance the human rights condition in Sudan, the violations and abuses of human rights have continued. There were numerous reports of involuntary or enforced disappearances, slavery, extra-judicial killings, summary executions, torture, and detention without due process of law, which took place between July and August 1992 in Juba. ${ }^{85}$ These violations and atrocities continue, and the international community has not effectively addressed the situation. ${ }^{86}$

The Sudanese Army battled the Sudanese People's Liberation Front Army (SPLA) in Juba and the surrounding areas in June and July, 1992. Government forces repelled the SPLA attack. Observers noted that security services arrested hundreds of military and civilian personnel after the battle ended; those detained included Sudanese nationals working with international aid agencies as well as international workers. ${ }^{87}$ The Special Rapporteur, in his 1994 report to the Commission on Human Rights, documented these incidents. Several employees who worked in Juba for the United States Agency for International Development (US AID), the European Commission, the United Nations Development Programme (UN DP), and the United Nations Children's Fund (UNICEF) were either killed during the fighting or sentenced to death within a few months after the fighting ended. ${ }^{88}$

The institution of slavery continues into the Twenty-first Century and thrives in the Sudan, where the government utilizes this atrocious institution as a means of advancing its policies. ${ }^{89}$ The oil fields in northern Sudan provide a financial motivator for the NIF government, which uses the ethnic cleansing policy as a tool for clearing the oil region of the indigenous population. ${ }^{90}$ Since the Sudanese government continues to perpetuate

84. See id. at 56-57.

85. See Situation of Human Rights in Sudan, supra note 74.

86. See Interview, supra note 79 (listing atrocities that include systematic rape, killing, torture, mutilation, and ethnic cleansing pursuant to the government sanctioned jihad, or holy war, in the Sudan).

87. See Situation of Human Rights in Sudan, supra note 74.

88. See id.

89. See Elizabeth Olson, Alarm Is Sounded on Slavery Labor Agency Reports Rise in Trafficking of People, INT'LHERALD TRIB., May 25, 2001, available at WL 4855049 (reporting that slavery continues and is openly practiced in the Sudan and Sierra Leone).

90. See Eric Reeves, Rapacious Instincts in Sudan: Oil Companies Are Partners With Khartoum in Waging a Cruel Civil War, 272:22 THE NATION (2001), available at $2001 \mathrm{WL}$ 2132616 (maintaining that the oil companies involved as business partners with NIF forces in Khartoum are accomplices to the travesties in the Sudan). 
atrocities against the civilian population, the U.N. vote that resulted in "booting the United States off the Human Rights Commission [HRC] . .." while at the same time voting the Sudan on to the HRC seems sadly ironic." Allowing the Sudan to participate in presiding over human rights violations is analogous to letting the proverbial fox watch the chicken coop.

The Sudanese government continues its gross violations of human rights and its policies exacerbate rather than alleviate the problem. Rather than promulgating policies that would improve the human rights situation, build public confidence, encourage community cooperation, and attract international volunteers who could aid the Sudanese people, the government turns a blind eye to the suffering that it imposes. These egregious human rights violations require immediate action, both by the Sudanese government and the international community.

The international community has taken some positive steps toward alleviating the human suffering in the Sudan, however more action is urgently needed. The international community should avoid repeating the mistake that it made in Rwanda when it allowed (by not implementing sufficient preventative procedures) the extremely cruel action taken by Hutu extremists on April 6, 1994 against the Tutsi minority in Rwanda. Within fours months of that date, between a half million and a million people, most of whom were Tutsis, were massacred.92 The human rights violations in $R$ wanda are beyond the scope of this commentary, however, they bear mention because they illustrate how easily a human rights situation can spiral out of control when the international community delays taking adequate steps to intervene and thereby preclude extreme and monumental loss of human life.

\section{CONCLUSIONS AND RECOMMENDATIONS}

Human rights constitute basic rights and freedom to which every human being is entitled. The state should protect against breaches of these rights by enforcing laws that pertain to the protection of human rights. Laws that protect human rights include national constitutions as well as international law, which provides universal protection. Human rights are fundamental rights that derive from natural as well as positive law. One positive law instrument that articulates basic human rights is the UDHR. Other positive law documents that express basic human rights are the French Declaration of the Rights of Man and of the Citizen of 1789 and the U.S. Constitution and Bill of Rights. The Universal Declaration of Human Rights of 1948 is the product of humane minded interpretations by people (including philosophers, theologians, and politicians) who aimed at preventing future atrocities similar to the Holocaust

91. The U.S. and the UN: Anti-American Gestures Are Part of a Sustained Ideological Assault, THE NAT'L POST, May 28, 2001, available at 2001 WL 22269980.

92. See International Human Rights Law, POLCY, AND PROCESS 313 (Newman \& Weissbrodt eds., 1996). 
from recurring. The UDHR is a proclamation outlining basic human rights; however, it is not binding international law. Though it is not binding, the UDHR has become the precedent and baseline for many international and regional conventions on human rights currently in effect. For example, the rights articulated in the UDHR provided the foundation for the ICCPR and the ICESCR. The UDHR also influenced various regional instruments, including the European Convention for the Protection of Human Rights and Fundamental Freedoms ${ }^{93}$ and the American Convention on Human Rights. ${ }^{94}$ The UDHR principles also inspired the African Charter on Human and People's Rights of $1981 . .^{95}$ The universal human rights principles of the UDHR propelled the regional human rights instruments, and the rights that these instruments delineate stem from the basic rights described in the UDHR. If the UDHR principles are universally accepted by all states as evidenced by the regional human rights documents that reflect the basic rights delineated in the UDHR, then why do egregious human rights violations persist? The principle that man must have recourse from human rights violations and that human rights should be protected by the rule of law remains as true today as it was in 1948.

Without the maintenance of the rule of law, violations of human rights recur and cause rebellion to ferment. Human rights violations impede maintenance of public order and security and exacerbate its deterioration. When the state uses law and order as a pretext for exerting overwhelming force against suspected criminals and employs torture to extract information and violence to stop demonstrations, it leads to abuse and violates human rights. It thereby exacerbates civil unrest, isolating the executive organs from the community, forcing police agencies to be reactive, rather than preventive in their approach, and eliciting international and media criticism and political pressure on the government. These methods create civil unrest.

One factor that fuels human rights violations is the division between citizens and government officials. The government officials retain all power, and the citizens remain subordinate. Therefore, civilians' thoughts naturally turn toward overthrowing the officials and seizing power themselves. This has frequently happened, particularly in developing countries. Under these circumstances, the violation of human rights is inevitable. In order to enhance the protection of human rights, government officials and entities should be seen as a part of the community, not as a separate mechanism or apparatus. Government officials should encourage a dialogue with the citizenry and thereby establish closer ties with the community. The executive bodies should work with the citizens and enlist their input regarding the assistance given by the media, the international community, and from political authorities.

93. See supra note 30.

94. See American Convention on Human Rights, Nov. 22, 1969, O.A.S. Treaty Series No. 36, at 1, OEA/Ser. L./V/II.23 doc. Rev. 2, entered into force July 18, 1978.

95. See supra note 34. 
Another reason for frequent human rights violations is that many ordinary people remain unaware of basic human rights principles. In other words, the concept of human rights, as articulated in international and regional conventions, and to some extent in the internal law of the various states, in most cases is not obvious to the civilian people. Furthermore, authorities frequently misinterpret the provisions of international law that pertain to human rights. Therefore, the international community should continue to contribute human rights assistance, conflict resolution, and peace building, but it must go a step further. In order to achieve its goal of advancing basic human rights, the international community must foster closer ties with the communities where violations occur and introduce the universally and internally recognized human rights concepts to the wide range of civilians. With greater knowledge, the community affected by human rights violations can be free from myth and fully understand the concept of human rights. This greater understanding will generate community confidence and cooperation and the peaceful resolution of conflicts by enabling the public to work with the police force rather than fear it. Thus, fostering human rights protections increases the stability of nations and bolsters the rule of law.

The practical effects of human rights violations in East Africa are multifaceted. The absence of public confidence in the authorities, the proliferation of civil unrest, and the disconnect of policy from the community are the usual practices. If the governments do not take urgent action, these conditions will lead to the destruction of statehood and barbaric living conditions.

Therefore, in order to improve the human rights situation in East Africa, the international community should establish another agency specifically designed to deal with the human rights violations. This agency should address the common human rights problems in East Africa, including excess border crossing of refugees from one East African country to another, the ongoing wars that force civilians to become refugees in neighboring countries, and civil laws and practices that generate inhumane treatment of refugees by police and other unauthorized (non-police) individuals. Because the abuses of human rights are common problems for all East African countries, there is a persistent need for a concerted action establishing a Central Agency for Protection of Human Rights in East Africa, which would be referred to as "CAPHREA." To facilitate this new agency, the international community should hold conferences that create resolutions and recommendations for the parties to the central agency. These recommendations and resolutions shall be accessible to the broad range of the peoples and individuals of the member countries via the countries' mass media and any other viable means of disseminating information. The results of meetings or conferences should be communicated to the U.N. agencies as well as NGOs that deal with human rights issues.

In East African countries, dispute resolution has principally centered on traditional mediation methods developed from deep-seated traditions and customs. Dispute resolution pursuant to mediation by wise people and elders, who were the traditional leaders, has not only been employed with regard to 
disputes between individuals belonging to the same ethnic groups but also with regard to disputes arising between different ethnic groups. Thus, dispute resolution pursuant to international norms and laws became difficult because it was not applied without reference to the traditional forms of mediation (relying on the wise men and elders). The traditional methods of dispute resolution prevailed and impeded effective resolution of disputes pursuant to international law. Thus, the aforementioned central agency should consider the traditional methods of dispute resolution and act accordingly. 
